
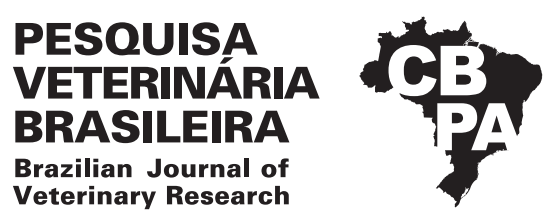

Pesq. Vet. Bras. 39(1):1-11, janeiro 2019 DOI: 10.1590/1678-5150-PVB-6293

Topic of General Interest

ISSN 0100-736X (Print)

ISSN 1678-5150 (Online)

\title{
Jürgen Döbereiner: a life dedicated to science ${ }^{1}$ Jürgen Döbereiner: uma vida dedicada à ciência ${ }^{1}$
}

\author{
Iveraldo S. Dutra ${ }^{2 *}$ (D), Axel Colling ${ }^{3}$, David Driemeier ${ }^{4}$, Marilene F. Brito ${ }^{5}$, \\ Daniel G. Ubiali ${ }^{5}$ (D) , Ana Lucia Schild ${ }^{6}$ (D) , Franklin Riet-Correa ${ }^{7}$ (D) \\ and Claudio S.L. Barros ${ }^{8}$
}

\begin{abstract}
Dutra I.S., Colling A., Driemeier D., Brito M.F., Ubiali D.G., Schild A.L., Riet-Correa F. \& Barros C.S.L. 2019. Jürgen Döbereiner: a life dedicated to science. Pesquisa Veterinária Brasileira 39(1):1-11. Setor de Anatomia Patológica, Departamento de Epidemiologia e Saúde Pública, Instituto de Veterinária, Universidade Federal Rural do Rio de Janeiro, Seropédica, RJ 23890-000, Brazil. E-mail: iveraldo.dutra@unesp.br

Dr. Jürgen Döbereiner was born in Germany, on the 1st of November 1923, and lived in Brazil for 68 years during which time he developed a range of scientific projects in veterinary pathology and related disciplines. His main interests were the identification of new poisonous plants and mineral deficiencies and the causes of "cara inchada" ("swollen face" a periodontal disease) and botulism in livestock. This research has resulted in the improved health and saving of hundreds of thousands of animals, mainly cattle, annually, and is consequently of enormous economic value to the country. This contribution remains largely under appreciated. He was also involved in organizing diagnostic methods for identifying infectious diseases such as African swine fever and glanders in horses. One of his other major achievements has been the foundation and editing of specialized scientific journals for the documentation of veterinary science research results. At the beginning of his career in the 1950s, he and colleagues from the Institute for Animal Biology (IBA) were struggling to find a national scientific journal where research results from veterinary medicine could be published with practical application to the Brazilian reality. In consequence, the team founded "Arquivos do Instituto de Biologia Animal" and published three volumes (1959-1961). He then founded and edited "Pesquisa Agropecuária Brasileira" (The Brazilian Journal of Agricultural Research") that included a veterinary section. A series of veterinary volumes were published (1966-1976). Finally, in 1978 he helped create the Brazilian College of Veterinary Pathology (CBPA) that published "Pesquisa Veterinária Brasileira" (The Brazilian Journal of Veterinary Research) from 1981. The main goal was to communicate the most relevant disease problems of Brazilian livestock, in particular pathology and related subjects such as epidemiology, clinical study series and laboratory diagnosis to field veterinarians and academics. Dr. Jürgen Döbereiner was president of CBPA (1978-2018) and chief editor of "Pesquisa Veterinária Brasileira" (1981-2018). He passed away on the 16th of October, 2018, at the age of 94 at his home in Seropédica/RJ, Brazil.
\end{abstract}

INDEX TERMS: Science, livestock diseases, diagnosis, veterinary pathology, poisonous plants, mineral deficiencies, periodontal disease, botulism.

\footnotetext{
${ }^{1}$ Received on December 3, 2018.

Accepted for publication on December 17, 2018.

${ }^{2}$ Departamento de Apoio, Produção e Saúde Animal, Faculdade de Medicina Veterinária, Universidade Estadual Paulista "Julio de Mesquita Filho" (Unesp), Rua Clóvis Pestana 793, Jardim Dona Amélia, Araçatuba, SP 16050-680, Brazil. *Corresponding author: iveraldo.dutra@unesp.br

${ }^{3}$ Australian Animal Health Laboratory, CSIRO, 5 Portarlington Road, 3219 Newcomb, Victoria, Australia.

${ }^{4}$ Setor de Patologia Veterinária, Faculdade de Veterinária, Universidade Federal do Rio Grande do Sul (UFRGS), Av. Bento Gonçalves 9090, Prédio 42505, Porto Alegre, RS 91540-000, Brazil.
}

\footnotetext{
${ }^{5}$ Setor de Anatomia Patológica, Departamento de Epidemiologia e Saúde Pública, Instituto de Veterinária, Universidade Federal Rural do Rio de Janeiro (UFRRJ), Seropédica, RJ 23890-000, Brazil.

${ }^{6}$ Laboratório Regional de Diagnóstico, Faculdade de Veterinária, Universidade Federal de Pelotas (UFPel), Campus Capão do Leão s/n, Capão do Leão, RS 96160-000, Brazil.

${ }^{7}$ Instituto Nacional de Investigación Agropecuaria (INIA), Estación Experimental INIA La Estanzuela, Ruta $50 \mathrm{Km}$ 11, Colonia del Sacramento, Colonia, Uruguay.

${ }^{8}$ Laboratório de Patologia Animal, Faculdade de Medicina Veterinária e Zootecnia, Universidade Federal de Mato Grosso do Sul (UFMS), Av. Senador Felinto Müller 2443, Campo Grande, MS 79070-900, Brazil.
} 
RESUMO.- [Jürgen Döbereiner: uma vida dedicada à ciência]. Dr. Jürgen Döbereiner nasceu na Alemanha em 1 de novembro de 1923, durante 68 anos viveu no Brasil e desenvolveu trabalhos científicos no campo da patologia veterinária latu sensu. Sua contribuição científica de destaque foi em temas como plantas tóxicas de interesse pecuário, deficiências minerais em animais de produção, cara inchada (doença periodontal) dos ruminantes, botulismo e diagnóstico de doenças infecciosas. Estas pesquisas resultaram na melhoria da saúde e de centenas de milhares de animais, principalmente bovinos e, consequentemente, foram de enorme valor econômico para o país. Esta contribuição ainda permanece em grande parte subestimada. De grande destaque para a ciência brasileira foi ainda a sua atuação profissional na documentação científica de resultados de pesquisa. No início de sua carreira na década de 1950, Dr. Döbereiner e outros pesquisadores do Instituto de Biologia Animal (IBA) detectaram a necessidade de um periódico científico nacional para publicar resultados de pesquisas com aplicação pratica à realidade brasileira. Dessa iniciativa surgiram os Arquivos do Instituto de Biologia Animal, que publicou três fascículos (1959-1961), em seguida o Dr. Jürgen Döbereiner participou na fundação da revista Pesquisa Agropecuária Brasileira que publicou a Série Veterinária (1966-1976) e finalmente em 1978, houve a fundação do Colégio Brasileiro de Patologia Animal (CBPA) que publica desde 1981 a revista Pesquisa Veterinária Brasileira. Este periódico científico foi criado para apresentar à comunidade, principalmente veterinários de campo e professores, os principais problemas de saúde em animais de produção no Brasil, ou seja, patologia em seu sentido amplo, envolvendo as áreas de epidemiologia, clínica e diagnóstico laboratorial. Dr. Jürgen Döbereiner, que foi presidente do CBPA (1978-2018) e Editor-Chefe da revista Pesquisa Veterinária Brasileira (1981-2018), faleceu em casa, em 16 de outubro de 2018, aos 94 anos, no município de Seropédica/RJ.

TERMOS DE INDEXAÇÃO: Ciência, pecuária, doenças de rebanhos, diagnóstico, patologia veterinária, plantas tóxicas, deficiências minerais, doença periodontal, botulismo.

Jürgen Döbereiner (Fig.1) was born in Königsberg, former capital of East Prussia, Germany, 1st November 1923 (today Kaliningrad, Russia). From 1935 he went to secondary school in Berlin and graduated from high school in 1942. Being an excellent skier he served in the Austrian mountain artillery from 1942 to 1945 and was promoted to lieutenant during World War II.

After the war he studied veterinary medicine at the University of Munich, from 1947 to 1950. In March 1950 as a young student Jürgen married Johanna Kubelka, who just had obtained her degree in Agricultural Science. Johanna's family belonged to the Sudeten German speaking population of Czechoslovakia, who suffered from being displaced after the Second World War. In the same year Jürgen accepted an invitation from his father in law, Dr. Paul Kubelka (who had

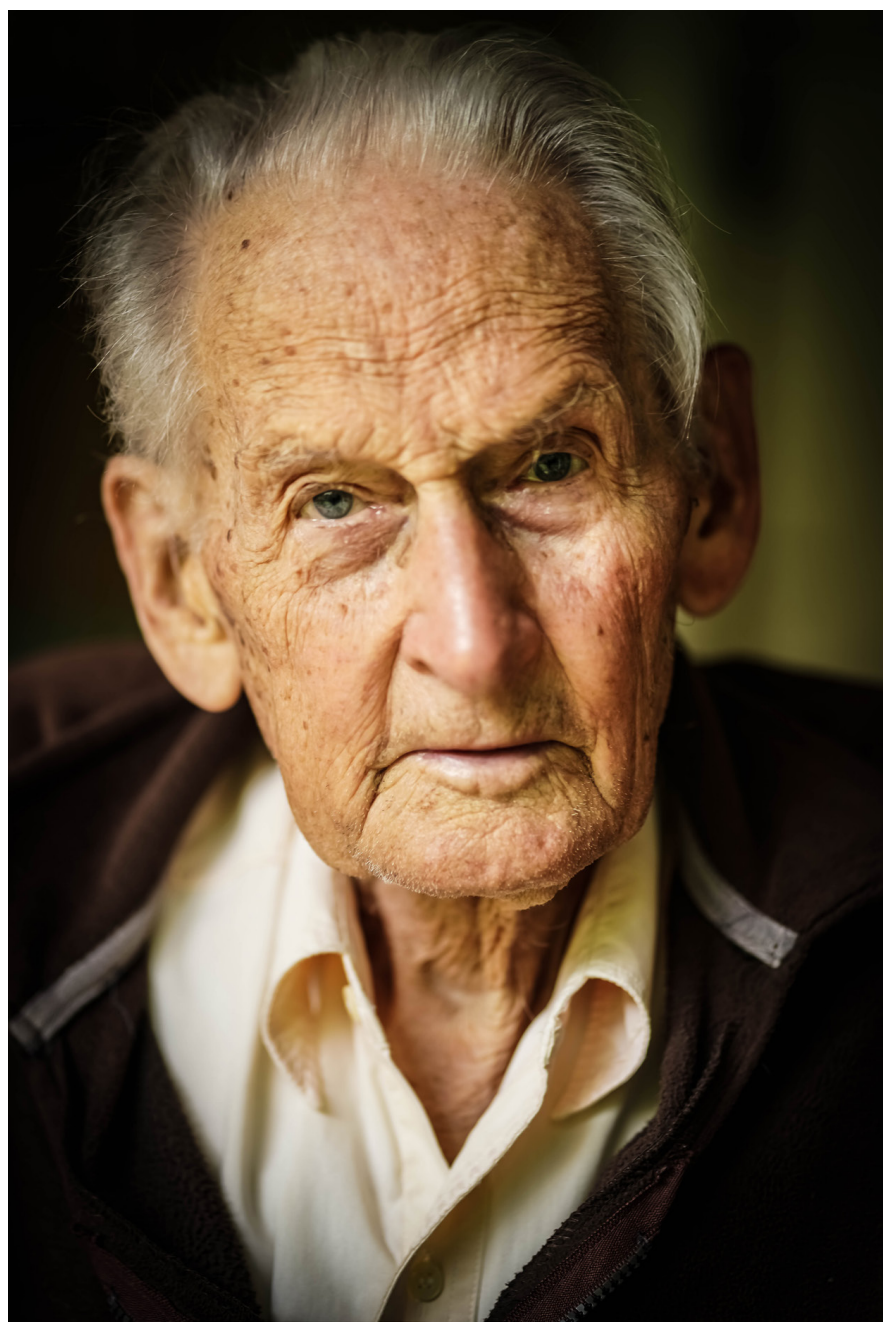

Fig.1. Jürgen Döbereiner (1923-2018), German-born, Brazilian citizen graduated as Veterinarian from "Universidade Federal Rural de Rio de Janeiro" (1954); scientific researcher and founder of the journal "Pesquisa Veterinária Brasileira”. Photo Jeann Leal, October 2018

Fig.1. Jürgen Döbereiner (1923-2018), alemão naturalizado brasileiro, graduou-se em Medicina Veterinária pela atual Universidade Federal Rural do Rio de Janeiro (1954), dedicou-se à pesquisa científica durante sua vida e fundou a revista Pesquisa Veterinária Brasileira. Foto de Jeann Leal, outubro de 2018.

Jürgen Döbereiner (Fig.1) nasceu em 1 de novembro de 1923, na cidade de Königsberg, na Prússia Oriental, Alemanha (hoje com nome de Kaliningrad, sob domínio russo). De 1935 a 1942 frequentou em Berlim escolas secundárias, finalizando-as com a madureza. Na Segunda Guerra Mundial, serviu na artilharia das montanhas austríacas, de 1942 a 1945, por ser um bom esquiador e após ter sido promovido a tenente.

Após a guerra estudou medicina veterinária de 1947 a 1950, na Universidade de München, Alemanha. Em março de 1950, ainda como estudante casou-se com a recém-formada Engenheira Agrônoma Johanna, cuja família pertenceu à população de língua alemã na Checoslováquia, que foi sumariamente expulsa após a Segunda Guerra Mundial. No mesmo ano aceitou o convite do sogro, Dr. Paul Kubelka (que tinha emigrado ao Brasil em 1948) de vir para o Rio 
emigrated to Brazil in 1948) to come to Rio de Janeiro. After transferring from the University of Munich to the Veterinary School of the Rural University of Brazil at Km 47 of the old Rio-Sao Paulo road in 1951, Jürgen met Carlos Hubinger Tokarnia and they began their close, productive and long lasting professional collaboration. Jürgen graduated from the National Veterinary School (today Universidade Federal Rural de Rio de Janeiro, UFRRJ) in 1954. Jürgen was registered as number 52 in the Regional Council of Veterinary Medicine of the state of Rio de Janeiro (CRMV/RJ).

From 1955 to 1976, he worked as a researcher at the Ministry of Agriculture in the "Seção de Anatomia Patológica" of the "Institute of Animal Biology" (IBA) at "Km 47" in Seropédica/RJ. From 1976 to 2010, he worked for the recently founded Embrapa (Brazilian Agency for Agriculture Research), which absorbed the IBA. Recently the collection of the former "Seção de Anatomia Patológica" was incorporated into the "Setor de Anatomia Patológica (SAP)" of the "Instituto de Veterinária" of UFRRJ.

During the late 1950s, Dr. Jürgen Döbereiner and his colleagues Carlos Tokarnia, Camilo Canella and Jerome Langenegger became research pioneers in Brazilian veterinary medicine. Tokarnia et al. (1959) contributed significantly to the de-mystification of a disease called "mal dos chifres", a purulent sinusitis idiosyncratically inflicted on bovines when cutting horns too deep. During field visits, clinical examinations and post mortems were performed on bovines from 17 farms in the states of Bahia, Pernambuco, Paraíba, Rio Grande do Norte, Ceará, Piauí, and Maranhão (Fig.2). They concluded that the popular term "mal dos chifres" did not describe a specific disease or a group of diseases but rather clinical signs and lesions of diverse causes. At the same time Döbereiner \& Tokarnia (1959a) described an outbreak of malignant catarrhal fever (=coryza gangrenosa) in cattle in the state of Rio Grande do Norte and an outbreak of glanders in equines in the state of Rio de Janeiro (Langenegger et al. 1960).

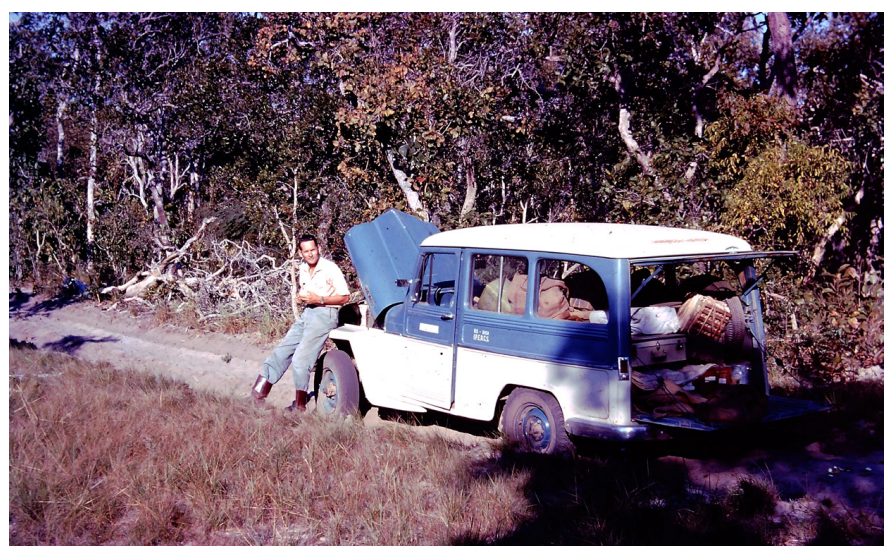

Fig.2. Dr. Jürgen Döbereiner and Carlos Tokarnia travelled over $9,000 \mathrm{~km}$ through the Northeast region of Brazil during the $1950 \mathrm{~s}$ to investigate the condition popularly known as "mal dos chifres".

Fig.2. Dr. Jürgen Döbereiner e Carlos Tokarnia viajaram mais de $9.000 \mathrm{~km}$ na região Nordeste do Brasil, durante a década de 1950, para investigar a condição popularmente conhecida como "mal dos chifres". de Janeiro. Assim, Jürgen transferiu-se da Universidade de München para a Universidade Rural do Brasil, no Km 47 da antiga Estrada Rio-São Paulo, em 1951. Neste mesmo ano ainda como estudante de medicina veterinária, Jürgen Döbereiner conheceu Carlos Hubinger Tokarnia, o que resultou em estreita colaboração profissional. Döbereiner formou-se em 1954 pela Escola Nacional de Veterinária (hoje, Universidade Federal Rural do Rio de Janeiro, UFRRJ). Jürgen foi registrado como número 52 no Conselho Regional de Medicina Veterinária do estado do Rio de Janeiro (CRMV/RJ).

De 1955 a 1976, trabalhou como pesquisador do Ministério da Agricultura na "Seção de Anatomia Patológica" do "Instituto de Biologia Animal" (IBA) no "Km 47", em Seropédica/RJ. De 1976 a 2010, trabalhou para a recém-fundada Embrapa, que absorveu o IBA. Recentemente a coleção e acervo da antiga "Seção de Anatomia Patológica" foi incorporada ao "Setor de Anatomia Patológica (SAP)" do Instituto de Veterinária da UFRRJ.

Já na segunda metade da década de 1950, Dr. Jürgen Döbereiner e seus colegas de pesquisa, Carlos Tokarnia, Camilo Canella e Jerome Langenegger realizaram trabalhos de pesquisa pioneiros. Tokarnia et al. (1959) participaram da elucidação de uma crença popular, principalmente na região Nordeste do Brasil, de uma condição conhecida como "mal dos chifres", que na realidade era uma condição causada pelas pessoas que perfuravam o chifre de bovinos e cursava com sinusite purulenta. Nesse trabalho, realizaram o exame clínico e necropsias de bovinos em 17 fazendas nos estados da Bahia, Pernambuco, Paraíba, Rio Grande do Norte, Ceará, Piauí e Maranhão (Fig.2). Concluíram que o "mal dos chifres" era um termo popular que não designava uma doença ou certo grupo de doenças, mas sim era usado para explicar sinais clínicos e lesões de diversas origens. Na mesma viagem tiveram a oportunidade de abordar e descrever um surto de febre catarral maligna (=coriza gangrenosa) em bovinos no estado do Rio Grande do Norte (Döbereiner \& Tokarnia 1959a). Em seguida relataram um surto de mormo em equinos no estado do Rio de Janeiro (Langenegger et al. 1960).

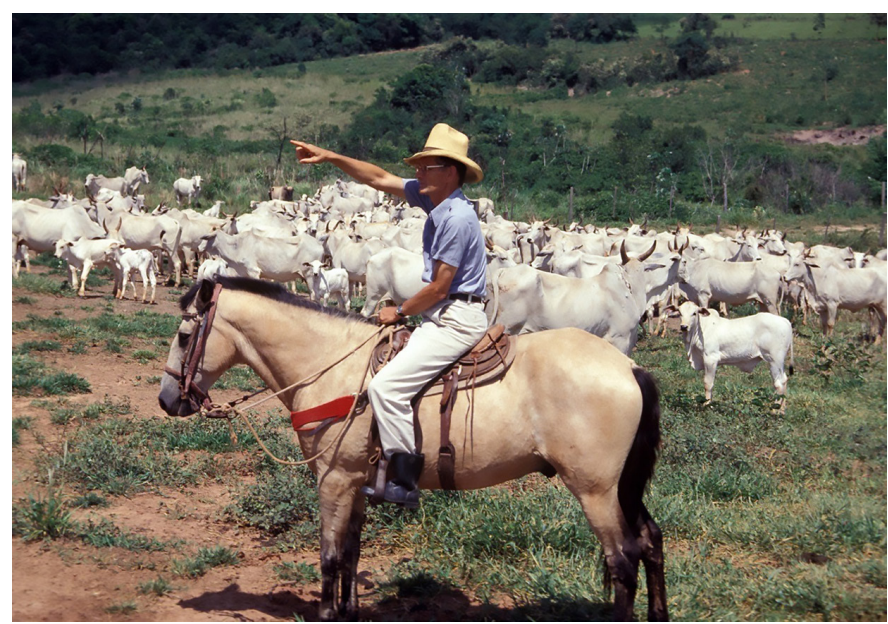

Fig.3. Jürgen Döbereiner travelling in Fazenda Recreio, Marília/SP, to investigate about infectious bovine periodontitis. October 1987.

Fig.3. Jürgen Döbereiner em uma viagem na Fazenda Recreio, Marília/SP, para investigação da periodontite infecciosa dos bovinos. Outubro de 1987. 
From 1959 to 1961 he was invited to be the chief editor of Arquivos do Instituto de Biologia Animal by the director of IBA.

From 1961 to 1963 Jürgen obtained his Master of Science at the University of Wisconsin, Madison, USA supported by a grant from the Rockefeller foundation. His dissertation was on the poisoning of bovines with "samambaia" braken fern plant, Pteridium aquilinum ( $=$ P. arachnoideum), which causes lesions in the bladder (Döbereiner et al. 1966). Further manuscripts were published later that described neoplastic lesions in the bladder and squamous cell carcinoma in the superior digestive tract of bovines consuming samambaia (Döbereiner et al. 1967, Tokarnia et al. 1969).

He founded the journal Pesquisa Agropecuária Brasileira and was chief editor 1966-1976 on the invitation of the Director General of the National Department of Research and Experimental Agriculture (DNPEA). Today this journal is published by Embrapa.

After returning from the USA he was offered a position at UFRRJ but preferred the better opportunity to work at IBA, the former Brazilian reference laboratory for animal health.

During the late 1960s until the mid 1990s he undertook 52 scientific expeditions (Fig.3) to 12 Brazilian states, in particular to the Midwest, North and Southeast. Jürgen documented all his trips in his travel diary (Döbereiner 2005). He was always accompanied by his necropsy box (Fig.4) and meticulously took notes of any relevant findings related to animal health problems, post mortems, farmers and observations from veterinarians and other professionals (Fig.5). Jürgen and collaborators worked on Solanum malacoxylon (=S. glaucophyllum), a plant that was associated with a disease called "Espichamento" after being consumed by bovines, in particular in the Brazilian Pantanal (Döbereiner et al. 1971, Tokarnia \& Döbereiner 1974). As an example that illustrates Jürgen's early endeavour to foster international collaboration and scientific networking, he extended his research on the pathological aspects and pathogenesis of poisoning with S. glaucophyllum at the Royal Veterinary College, London, UK, 1970-1971 supported by a Queen's scholarship (Sansom et al. 1971, Döbereiner \& Dämmrich 1974, Döbereiner et al. 1975a, 1977, Dämmrich et al. 1975, Done et al. 1976a, 1976b).

In recognition of his research in Brazil he received the title Doctor Honoris Causa from the Justus-Liebig-Universitaet Giessen, Germany as part of their 200 years anniversary of the Faculty of Veterinary Medicine in 1977.

He lectured courses for post-graduates at Master and PhD level at UFRRJ and University of Sao Paulo (USP) for many years.

In 1978 Tokarnia, Jürgen and others collaborated on the diagnosis of African Swine Fever (ASF) during an outbreak in Paracambi/RJ, close to IBA, which resulted in a swift containment and eradication of the epidemic in Brazil. Later, it was shown that a series of wrong interpretations of serological test results, suggested ASF was present in several Brazilian States (Tokarnia et al. 2004, Viana 2008).

From 1969 his research focused on the etiology, pathogenesis and epidemiology of a disease generally known as "swollen face of bovines" (Döbereiner et al. 1974). Supported by grants from the National Research Council (CNPq) and German Academic Exchange Service (DAAD) he undertook
De 1959 a 1961, foi Editor-Chefe dos Arquivos do Instituto de Biologia Animal a convite do diretor do IBA.

De 1961 a 1963, cursou o mestrado na Universidade de Wisconsin em Madison, como bolsista da Fundação Rockefeller, e obteve o título de Master of Science, com a defesa de dissertação relacionada às lesões em bexigas de bovinos intoxicados pela planta "samambaia", Pteridium aquilinum (=P. arachnoideum) (Döbereiner et al. 1966). Posteriormente foram publicados outros trabalhos sobre essa planta e associaram-se lesões neoplásicas de bexiga e carcinomas de células escamosas no trato digestório superior de bovinos com o consumo de samambaia (Döbereiner et al. 1967, Tokarnia et al. 1969).

Foi fundador da revista Pesquisa Agropecuária Brasileira e Editor-Chefe, de 1966 a 1976, a convite do diretor-geral do Departamento Nacional de Pesquisa e Experimentação Agropecuária (DNPEA). Esta revista hoje está sendo publicada pela Embrapa.

Após o regresso dos Estados Unidos, fez concurso na Universidade Federal Rural do Rio de Janeiro, mas não tomou posse por considerar as condições de pesquisa melhores no IBA, o antigo laboratório de referência em sanidade animal do Brasil.

A partir do final da década de 1960 e até meados da década de 1990, realizou 52 expedições científicas (Fig.3) a diferentes municípios de doze estados brasileiros, com destaque aos localizados nas regiões Centro-Oeste, Norte e Sudeste, todas registradas nos seus Diários de Viagem (Döbereiner 2005). Sempre acompanhado da sua caixa de necropsia (Fig.4), tinha o cuidado de anotar todas as informações relacionadas aos problemas de saúde animal, objeto das suas linhas de pesquisa, das necropsias realizadas e dos contatos com proprietários rurais, médicos veterinários e outros profissionais a quem recorria (Fig.5).

Em 1971, o grupo de pesquisas do qual o Dr. Döbereiner participava associou o consumo de Solanum malacoxylon (=S. glaucophyllum) com a doença popularmente conhecida como "espichamento" e que na ocasião afetava bovinos, sobretudo no Pantanal do Brasil (Döbereiner et al. 1971, Tokarnia \& Döbereiner 1974). Em 1970/71, realizou pelo Queen's Scholarship estudos no Royal Veterinary College em Londres sobre a intoxicação por S. malacoxylon. Em estreita colaboração internacional, o que sempre caracterizou a sua atuação como pesquisador, envolveu-se com os aspectos patológicos da intoxicação e a patogênese desta doença (Sansom et al. 1971, Döbereiner \& Dämmrich 1974, Döbereiner et al. 1975a, 1977, Dämmrich et al. 1975, Done et al. 1976a, 1976b).

De 1976 a 2010, atuou como pesquisador da recém-criada Embrapa.

Em 1977, foi contemplado com o título de Doctor Honoris Causa pela Justus-Liebig-Universitaet Giessen, Alemanha, por ocasião da comemoração de 200 anos da Faculdade de Medicina Veterinária em face dos trabalhos de pesquisa realizados no Brasil.

Lecionou nos cursos de pós-graduação de Mestrado e Doutorado da UFRRJ e Universidade de São Paulo (USP).

Em 1978 Jürgen, Tokarnia e outros pesquisadores realizaram o diagnóstico de um surto de peste suína africana que ocorreu no município de Paracambi/RJ, próximo ao IBA, o que resultou na rápida extinção deste foco no Brasil. Após a realização deste diagnóstico, houve uma série de interpretações equivocadas de exames sorológicos que consideraram 
studies to explain this unusual periodontitis in collaboration with the University of Giessen and Berlin from 1984 to 1989. In particular the collaboration with Prof. Dr. Hans Blobel, Director of the Institute for Bacteriology and Immunology of the Justus-Liebig-Universität Giessen, resulted in the discovery of bacterial involvement in the etiology and pathogenesis of the disease. Some epidemiological aspects of the disease, such as the improvement of calves after being moved to healthy, balanced soils, were observed (Döbereiner et al. 1975b, 1976). Studies on bacterial involvement showed the relevance of specific genera such as Treponema, Porphyromonas and Prevotella (=Bacteroides melaninogenicus) (Blobel et al. 1984, 1987, Botteon et al. 1993, Dutra et al. 2000, Döbereiner et al. 2004, Borsanelli et al. 2015a, 2015b). Subsequently a series of experiments provided evidence that "swollen face" was a multifactorial, bacterial disease rather than a specific mineral deficiency (Döbereiner et al. 1990, Moraes et al. 1999). An important diet-related factor for "swollen face" to occur is a disturbed balance of bacteria in the soil following forest clearing, which facilitates the production of in situ antibiotics. These have a direct or indirect impact on the buccal microbiotic flora (Döbereiner et al. 1987, 2000, Dutra et al. 1993a, diagnóstico de peste suína africana em diversas regiões do Brasil (Tokarnia et al. 2004, Viana 2008).

Desde 1969 dedicou-se à documentação da etiologia, patogênese e epidemiologia da doença popularmente conhecida como "cara inchada dos bovinos" (Döbereiner et al. 1974). Sob financiamento do CNPq e do Serviço de Intercâmbio Acadêmico Alemão (DAAD) realizou em 1984 e 1989 estudos sobre esta periodontite dos ruminantes nas Universidades de Giessen e Berlin. Um destaque especial nesses estudos foi a sua colaboração com o Prof. Dr. Hans Blobel, Diretor do Instituto de Bacteriologia e Imunologia da Universidade Justus-Liebig, de Giessen, Alemanha, que resultou nos estudos inéditos sobre a participação de bactérias na etiopatogenia da cara inchada. Além dos avanços no estudo da doença, esta colaboração possibilitou a formação de um considerável e efetivo quadro de pesquisadores brasileiros e alemães (Dutra et al. 1993a, Kopp et al. 1996, Schmitt et al. 1996, Döbereiner \& Dämmrich 1997, Grassmann et al. 1997). Alguns aspectos epidemiológicos desta doença foram elucidados como a recuperação de bezerros transferidos para pasto de área considerada indene (Döbereiner et al. 1975b, 1976). Os estudos bacteriológicos resultaram na identificação de uma ampla

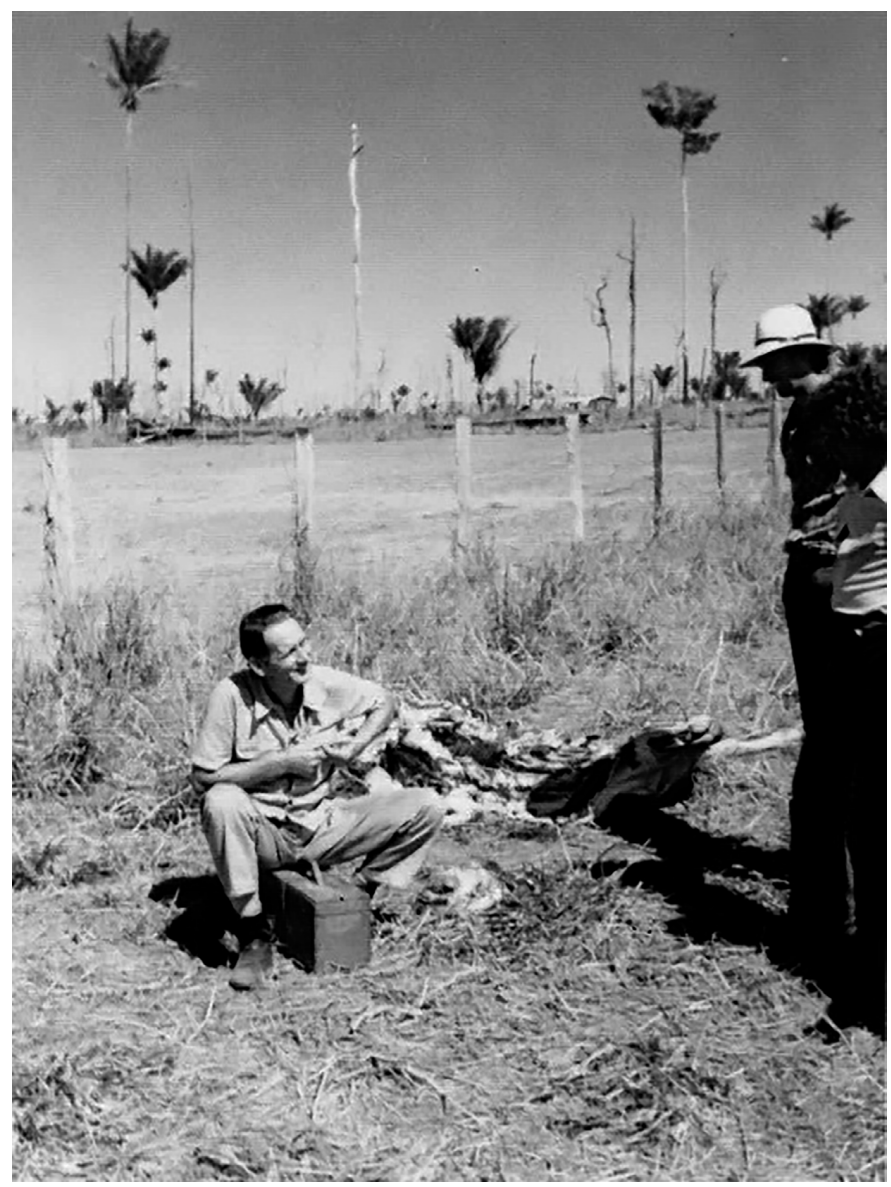

Fig.4. Dr. Jürgen sitting on a necropsy box after finishing a post mortem and taking specimens for diagnostic examination and research of bovine diseases. September 1975.

Fig.4. Dr. Jürgen sentado sobre a caixa de necropsia após ter realizado a necropsia e a coleta de material de pesquisa para diagnóstico de doença em bovinos. Setembro de 1975.

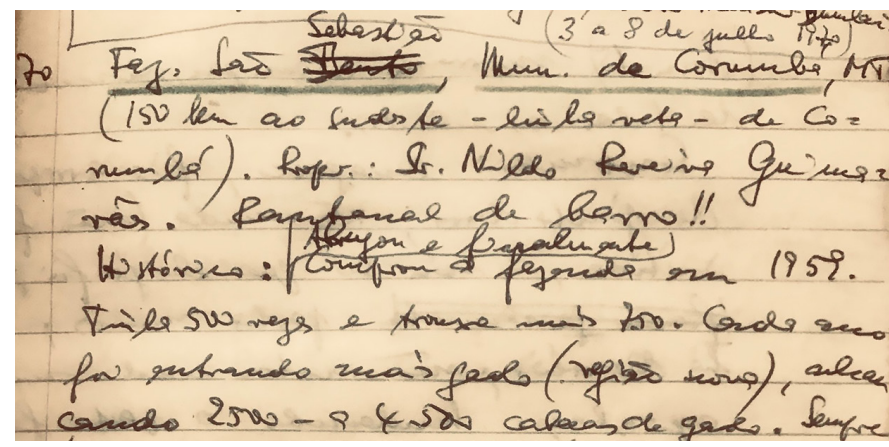

Fig.5. Notes from Jürgen's research diary, Corumbá/MS, 1970.

Fig.5. Anotações de Jürgen em seu diário de pesquisa, Corumbá/MS, 1970.

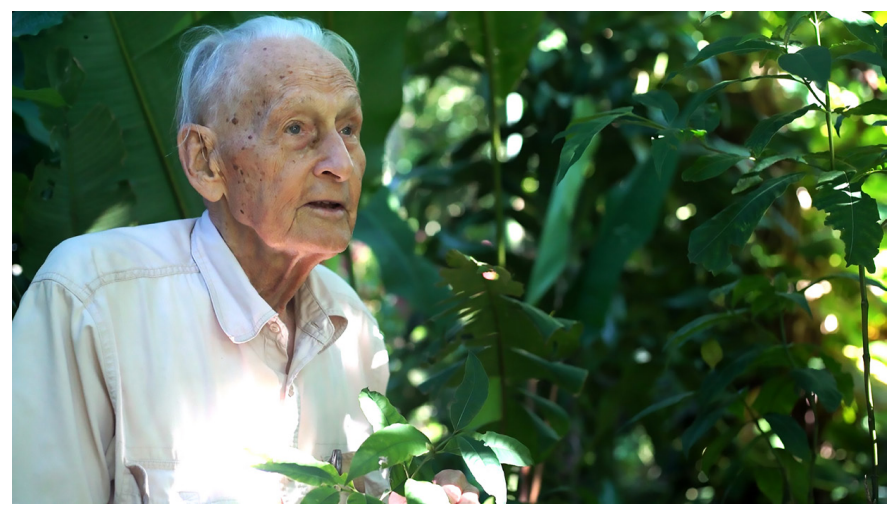

Fig.6. Jürgen Döbereiner telling stories about his research at his resort "Porangaba", Itaguaí/RJ. Beside him a specimen of Palicourea marcgravii, an important poisonous plant for Brazilian livestock. April 2018.

Fig.6. Jürgen Döbereiner em seu sítio Porangaba, em Itaguaí/RJ contando suas histórias de pesquisa ao lado de um exemplar de Palicourea marcgravii, importante planta tóxica para a pecuária brasileira. Abril de 2018. 
Kopp et al. 1996, Schmitt et al. 1996, Döbereiner \& Dämmrich 1997, Grassmann et al. 1997). Results further contributed to the prophylaxis (Döbereiner et al. 1990) and control (Rosa et al. 1985, Tims et al.1992) of the disease. In addition to the scientific advances, collaboration facilitated the development of a new generation of scientists from Brazil and Germany (Dutra et al. 1993a, Kopp et al. 1996, Schmitt et al. 1996, Grassmann et al. 1997).

Döbereiner was also co-author of two books titled: Plantas Tóxicas da Amazônia a Bovinos e Outros Herbívoros (Tokarnia et al. 1979, 2007) and Plantas Tóxicas do Brasil para Animais de Produção (Tokarnia et al. 2000a, 2012) and co-author of a book entitled: "Deficiências Minerais em Animais de Produção" (Tokarnia et al. 2010). The diagnosis and systematic study of poisoning plants for ruminants, carried with Tokarnia, showed the importance of plant poisoning in Brazil and allowed the scientific advance on measures of control and prophylaxis. Using data from diagnostic laboratories from different regions in Brazil, Pessoa et al. (2013) calculated the loss of livestock due to the ingestion of poisonous plants and estimated the following annual losses: 820,761 to $1,755,763$ cattle, 399,800 to 445,309 sheep, 52,675 to 63,292 goats and 38,559 horses. In April 2008, Dr. Jürgen Döbereiner talked about poisonous plants when he was being filmed (Fig.6). The picture shows him on his smallholding "Porangaba", near Itaguaí/RJ, next to Palicourea marcgravii, a poisonous plant causing sudden death in cattle, known as "cafezinho", or "erva-de-rato". This specimen had originally been planted and raised by Prof. Carlos Tokarnia in his house and both had used it to teach their students about the morphology and characteristic scent of $P$. marcgravii during practical sessions on poisonous plants. This is the most important poisonous plant in the country and is thought to be responsible for something like $90 \%$ of sudden death in the Brazilian herd. It has a wide geographic distribution but is not found in the South or in the Pantanal. It is found in the state of Rio de Janeiro in the region above of Serra das Araras (altitude above 550 meters). It is not found at lower altitudes, for example, in the Baixada Fluminense (Tokarnia et al. 2012).

Thiloa glaucocarpa (=Combretum glaucocarpum), also known as "sipaúba" or "vaqueta", causes outbreak of poisoning shortly after the beginning of the rainy season in the Northern Caatinga. Bovines develop clinical signs after 5-8 days and get sick 10-25 days after the first rainfall. T. glaucocarpa poisoning happen during or soon after this initial fast growth. After that period there are other plants available for consumption. (Tokarnia et al. 1981, 1994, 2002, 2012). This research on Palicourea marcgravii (Döbereiner \& Tokarnia 1959b) and T. glaucocarpa (Tokarnia et al. 1981, 1994) illustrate the team's pioneering research to discover the many poisonous plants affecting livestock.

After the diagnosis of botulism in the "agreste" of Piauí (Tokarnia et al. 1970), Dr. Döbereiner and colleagues undertook a variety of epidemiological investigations into epizootic botulism in diverse regions of Brazil (Langenegger \& Döbereiner 1988, Döbereiner et al. 1992, Dutra et al. 2001, 2005). The team described the connection between outbreaks of botulism and osteophagy, the eating of the bones of dead cattle in regions with very low soil phosphate contents. The role of water and food as vectors provided crucial information to bridge the gap

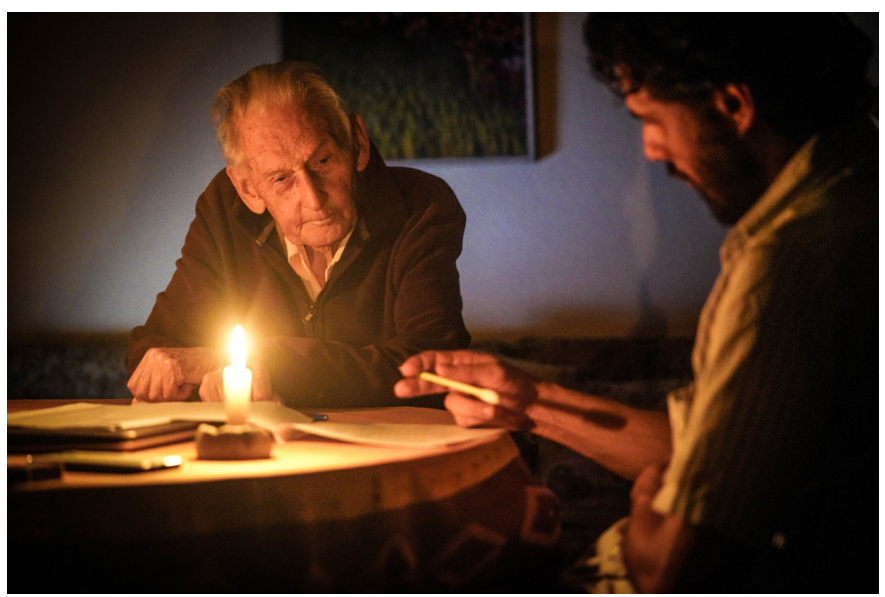

Fig.7. Jürgen Döbereiner with Daniel Guimarães Ubiali, October 10, 2018. While they were discussing the January 2019 edition for the "Pesquisa Veterinária Brasileira" journal, there was a fall in electric energy and they kept on working by the light of a candle! Photo Jeann Leal, October 2018.

Fig.7. Jürgen Döbereiner e Daniel Guimarães Ubiali no dia 10 de outubro de 2018. Ao programar juntos o fascículo de janeiro de 2019 da revista Pesquisa Veterinária Brasileira, acabou a energia e trabalharam à luz de velas! Foto de Jeann Leal, outubro de 2018.

microbiota de patógenos potenciais associada à doença. Dentre os micro-organismos destacam-se os gêneros Treponema, Porphyromonas e Prevotella (=Bacteroides melaninogenicus) (Blobel et al. 1984, 1987, Botteon et al. 1993, Dutra et al. 2000, Döbereiner et al. 2004, Borsanelli et al. 2015a, 2015b). Por meio de uma série de estudos, estabeleceram que a "cara inchada" tratava-se de uma doença multifatorial bacteriana e não relacionada com deficiência mineral específica (Döbereiner et al. 1990, Moraes et al. 1999). Um importante fator ambiental que estaria relacionado com a ocorrência da cara inchada seria decorrente do desequilíbrio na microbiota do solo e que envolveria a formação in situ de antibióticos, atuando assim direta ou indiretamente na disbiose da microbiota bucal por meio da dieta (Döbereiner et al. 1987, 2000, Dutra et al. 1993a, Kopp et al. 1996, Schmitt et al. 1996, Grassmann et al. 1997). Nesta linha de estudos os trabalhos resultaram ainda no desenvolvimento de medidas profiláticas (Döbereiner et al. 1990) e de controle (Rosa et al. 1985, Tims et al. 1992) da cara inchada dos bovinos.

Döbereiner foi ainda coautor das duas edições dos livros Plantas Tóxicas da Amazônia a Bovinos e outros Herbívoros (Tokarnia et al. 1979, 2007) e Plantas Tóxicas do Brasil para Animais de Produção (Tokarnia et al. 2000a, 2012), e também do livro Deficiências Minerais em Animais de Produção (Tokarnia et al. 2010). 0 estudo sistemático sobre o diagnóstico e os quadros clínico patológicos de intoxicação por plantas em ruminantes, realizado com o Professor Tokarnia, mostrou a importância da intoxicação por plantas no Brasil e permitiu o avanço científico sobre medidas de controle e profilaxia. Pessoa et al. (2013) calcularam através de dados dos laboratórios de diagnóstico de diferentes regiões do país a quantidade de mortes de animais de produção atribuídas ao consumo de plantas tóxicas. As perdas anuais por mortes de animais foram estimadas em 820.761 a 1.755 .763 bovinos, 


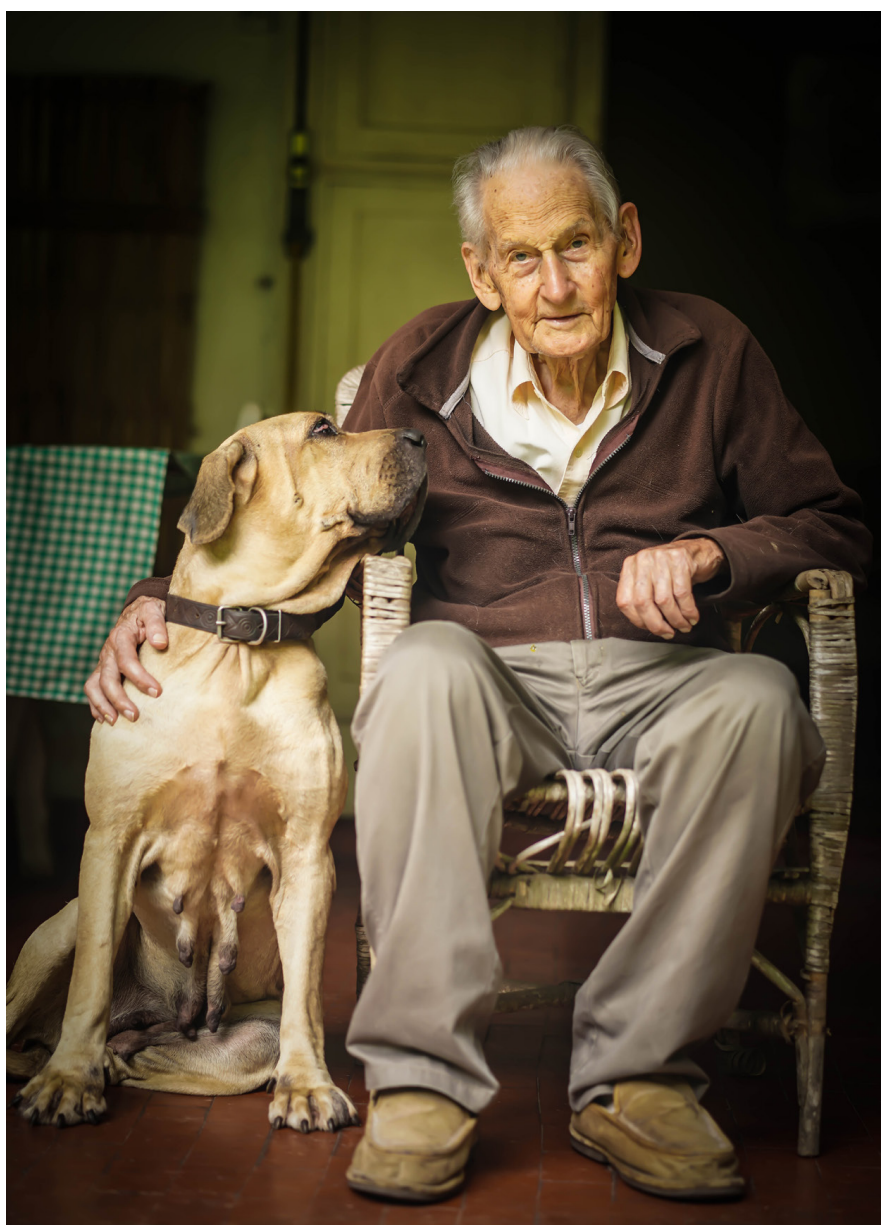

Fig.8. Jürgen Döbereiner at his residence, Seropédica/RJ, Km 47. Photo Jeann Leal, October 2018.

Fig.8. Jürgen Döbereiner em sua residência, em Seropédica/RJ, Km 47. Foto de Jeann Leal, outubro de 2018.

between research and extension and has turned Brazil into the largest global market for anti-botulism vaccines.

According to Dr. Döbereiner the historic experiences with botulism as well as other public health issues revealed the need to develop an integrated animal health system for the country. This should be based on combining practical information from field veterinarians with on and off farm laboratory diagnostics integrated by modern information technology. Diverse discussions about the etiology of the "mysterious disease" or "fallen cow disease", although legitimate delayed the extension of proper diagnosis, control and prevention which has led to the unnecessary loss of millions of bovines during many decades (Tokarnia et al. 2010).

In the 1990s, when Dr. Döbereiner was looking for a diagnostic test for botulism with good sensitivity and specificity, he was involved in an international collaboration with Embrapa, the Department of Preventive Veterinary Medicine of the Faculty of Agriculture and Veterinary Science (Unesp/Jaboticabal) and Dr. Hans-Erich Weiss, a veterinarian from a diagnostic institute in Heidelberg, Germany. They adapted the Complement Fixation Test for the diagnosis of botulism. The scientific impact of their achievements led to a breakthrough for consolidating modern diagnosis and the resulting control of the disease in Brazil
399.800 a 445.309 ovinos, 52.675 a 63.292 caprinos e 38.559 equinos.

Em abril de 2018, Dr. Jürgen Döbereiner contava histórias de pesquisa sobre plantas tóxicas enquanto estava sendo filmado (Fig.6). O exemplar de Palicourea marcgravii, conhecida como "cafezinho" ou "erva-de-rato", está plantada no sítio "Porangaba", em Itaguaí/RJ; este exemplar estava na casa do professor Carlos Tokarnia. Em aulas práticas sobre plantas tóxicas, os pesquisadores mostravam aos estudantes a morfologia e o aroma característico de P. Marcgravii. Esta planta tóxica tem larga distribuição geográfica no Brasil, com exceção da região Sul e do Pantanal. No estado do Rio de Janeiro P. marcgravii está presente na região acima da Serra das Araras (altitude 550 metros ou mais) e está ausente na Baixada Fluminense (Tokarnia et al. 2012).

0 pioneirismo no campo das plantas tóxicas de interesse pecuário pode ser exemplificado entre outros, pelo estudo de Palicourea marcgravii (Döbereiner \& Tokarnia 1959b) e pelo estudo de Thiloa glaucocarpa (=Combretum glaucocarpum) (Tokarnia et al. 1981, 1994). Esta planta, conhecida como "sipaúba" ou "vaqueta", causa intoxicação sob a forma de surtos no começo da estação chuvosa em regiões de Caatinga. Os bovinos adoecem entre o $10^{\circ}$ e 25ํํㄹ dias, após a primeira chuva, a evolução clínica é de 5-8 dias. T. glaucocarpa tem crescimento rápido no início da brotação e após esse período o crescimento é mais lento. A intoxicação ocorre na fase inicial da brotação, após esse período há disponibilidade de outras plantas para o consumo dos bovinos (Tokarnia et al. 1981, 1994, 2002, 2012).

Após o diagnóstico do botulismo no agreste do Piauí (Tokarnia et al. 1970), Dr. Döbereiner e colaboradores realizaram diversos estudos epidemiológicos sobre o botulismo epizoótico em diversas regiões brasileiras (Langenegger \& Döbereiner 1988, Döbereiner et al. 1992, Dutra et al. 2001, 2005). Assim, descreveram surtos da doença associados à osteofagia, à veiculação hídrica e aos alimentos; sempre conjugando as atividades de pesquisa às de extensão e que resultaram hoje em dia no maior mercado mundial de vacinas anti-botulínicas. De importante contexto histórico o botulismo, assim como diversos outros problemas sanitários, revelava a necessidade na visão do Dr. Döbereiner de um sistema de saúde animal em que a base seria o diagnóstico realizado nas propriedades rurais por médicos veterinários e um sistema de informação. As diversas discussões sobre a etiologia da "doença misteriosa", ou "doença da vaca caída", embora legítimas, atrasaram a divulgação das medidas de diagnóstico, controle e prevenção dessa enfermidade, que no seu curso natural causou a perda de milhões de bovinos nas décadas de 1980-1990.

Na década de 1990, diante da necessidade de se buscar um teste diagnóstico com boa sensibilidade e especificidade novamente o Dr. Döbereiner procurou a colaboração internacional. Nesse contexto, com o auxílio da Embrapa e do Departamento de Medicina Veterinária Preventiva da Faculdade de Ciências Agrárias e Veterinárias da Unesp/Jaboticabal estabeleceu uma parceria com o Dr. Hans-Erich Weiss, veterinário de um instituto de diagnóstico de Heidelberg, Alemanha, que havia adaptado a técnica de fixação de complemento para o diagnóstico do botulismo. Os trabalhos científicos resultantes dessas ações e da equipe foram de grande valor para consolidar uma nova etapa no diagnóstico e controle da doença no país 
(Dutra et al. 1993b, Menegucci et al. 1998, Silva et al. 1998, Souza et al. 2006, Curci et al. 2007).

Research into mineral deficiencies had a breakthrough with the investigation of an outbreak of enzootic ataxia of ovines in Piauí state (Döbereiner et al. 1966). Evaluation of a series of results demonstrated the importance of field veterinarians with experience in the diagnosis of animal disease based on clinical and pathological findings and confirmatory testing by analysis of minerals in animal tissues (Tokarnia et al. 1988, 1999, Pilati et al. 1996, Moraes et al. 1999). The authors further provided evidence that increased levels of minerals in the diet, mainly phosphorus as well as mineral deficiencies of specific elements such as phosphorus, sodium, copper and cobalt, are the main reasons for economic losses (Tokarnia et al. 2000b, 2012, Malafaia et al. 2014).

From undergraduate level and throughout many years of his research career, Dr. Jürgen Döbereiner was supported by grants from CNPq. He published 174 papers in national and international science journals and supervised many postgraduates.

From 2000 to 2004 he was president of the Brazilian Association of Scientific Editors (ABEC) during two consecutive periods (2000-2001 and 2002-2003) and collaborated tirelessly for the growth of the organization.

Dr. Jürgen together with other colleagues (Carlos Hubinger Tokarnia, Severo Sales de Barros, Jerome Langenegger, Hugo Edson Barbosa de Rezende, Rubens Pinto Melo and Laerte Grisi) founded the Brazilian College of Animal Pathology (CBPA) with the goals of promoting the importance of Veterinary Medicine and having a national scientific journal of veterinary medicine. Dr. Jürgen was president of CBPA from 1978 to 2018.

In 1981, CBPA published the first volume of the journal Pesquisa Veterinária Brasileira. The main objective of this scientific journal was to communicate to the public, in particular to field veterinarians and academics the main health problems of livestock in Brazil, in particular pathology and related subjects such as epidemiology, clinical findings and laboratory diagnosis. The journal was edited monthly from 2007 and included additional topics such as Small Animals, Wildlife Medicine and Animal Morphophysiology. From the first edition Pesq. Vet. Bras. was indexed by the prestigious international database, Thomson Reuters, and recently as Qualis A2 by CAPES. Another goal of Dr. Jürgen was to extend the indexation of Pesq. Vet. Bras. to the global PubMed database. CBPA has signed the terms for cooperation with UFFRJ and the University of Brasilia (UnB) to improve publication and visibility of the journal. From 2019 onwards, all manuscripts will be published in English with a summary in Portuguese. A new service is now available that allows the publishing of high quality images similar to other international scientific journals in the field of veterinary pathology. Jürgen worried about the future of the journal and engaged in many philosophic discussions to encourage young junior academics to carry his ideas and journal forward (Fig.7).

Jürgen lived on the University Campus, Km 47 (Fig.8), also known as "Ecology" and lived in the same house from 1952-2018. Together with Johanna (his wife) and their three children Maria Luisa, Christian and Lorenz the family enjoyed the proximity between their home and IBA.

It is worthwhile mentioning that Dr. Döbereiner enjoyed to relax and recover during weekends at his smallholding "Sítio Porangaba", located in the maritime mountains of the
(Dutra et al. 1993b, Menegucci et al. 1998, Silva et al. 1998, Souza et al. 2006, Curci et al. 2007).

0 início dos estudos com deficiências minerais ocorreu com a descrição de um surto de ataxia enzoótica em ovinos no Piauí (Döbereiner et al. 1966) e a continuação de uma série de avaliações detectaram que o diagnóstico clínico patológico de deficiências minerais deve ser realizado por veterinário com experiência em diagnóstico de doenças e a confirmação deve ser realizada sobretudo com dosagens de minerais em tecidos do animal (Tokarnia et al. 1988, 1999, Pilati et al. 1996, Moraes et al. 1999). Verificaram também que as perdas econômicas na pecuária ocorrem tanto em função de dietas com excesso de elementos (principalmente fósforo) e quanto pela falta de determinado elemento na dieta (deficiência mineral, principalmente sódio, fósforo, cobre e cobalto) (Tokarnia et al. 2000b, 2012, Malafaia et al. 2014).

Desde estudante e nos muitos anos de pesquisa Dr. Jürgen Döbereiner, foi bolsista do CNPq, publicou 174 artigos em periódicos científicos nacionais e internacionais e orientou várias teses de pós-graduação.

Jürgen foi presidente da Associação Brasileira de Editores Científicos (ABEC) por dois mandatos consecutivos (2000-2001 e 2002-2003) e colaborou incansavelmente para o crescimento da ABEC.

Em 1978, Dr. Jürgen e outros colegas (Carlos Hubinger Tokarnia, Severo Sales de Barros, Professor Langenegger, Professor Hugo Edson Barbosa de Rezende, Rubens Pinto Melo e Professor Laerte Grisi) fundaram o Colégio Brasileiro de Patologia Animal (CBPA), com o objetivo da edição de um periódico científico de medicina veterinária de âmbito nacional. Dr. Jürgen foi presidente do CBPA de 1978 a 2018.

Em 1981, o CBPA publicou o primeiro fascículo da revista Pesquisa Veterinária Brasileira. Este periódico científico foi criado para apresentar à comunidade, principalmente veterinários de campo e professores, os principais problemas de saúde em Animais de Produção/Livestock Diseases no Brasil, ou seja, patologia em seu sentido amplo, envolvendo as áreas de epidemiologia, clínica e diagnóstico laboratorial. A partir de 2007, a revista passou a ter periodicidade mensal e ampliou a sua abrangência ao publicar artigos das áreas de Pequenos Animais/Small Animal Diseases, Animais Selvagens/ Wildlife Medicine e Morfofisiologia/Animal Morphophysiology. A Pesq. Vet. Bras. foi desde o primeiro fascículo, indexada pela prestigiada base de dados internacional Thomson Reuters e, recentemente, foi classificada pela CAPES como Qualis A2. A partir de 2019, todos os artigos serão publicados em inglês e com um resumo em português. Recentemente foi incorporado o serviço de edição de imagens como exemplo de importantes periódicos científicos internacionais da área de Patologia Veterinária. Um dos objetivos de Dr. Jürgen era indexar a Pesq. Vet. Bras. na prestigiada base de dados PubMed. 0 CBPA firmou termos de cooperação técnica com a Universidade Federal Rural do Rio de Janeiro e com a Universidade de Brasília para aperfeiçoar a publicação e conquistar maior visibilidade para a Pesq. Vet. Bras. Jürgen se preocupava com a segurança da continuidade da publicação da revista, por isso, dedicou-se a ensinar várias filosofias sobre a publicação científica aos jovens professores com quem mantinha amizade (Fig.7).

Jürgen sempre residiu de 1952 a 2018 no bairro residencial da Universidade Rural, Km 47 (Fig.8), também conhecido como Ecologia; a proximidade de sua residência com o IBA permitiu uma qualidade de vida excelente a Jürgen, Johanna 
Mata Atlântica, near Itaguaí/RJ. He was a founding member and president of the Association of Environmental Heritage (APN) and his Sítio became one of the first Environmental Reserves for Environmental Heritage (RPPN) in the state of Rio de Janeiro. These examples demonstrate his sensibility and early awareness for the need to conserve and promote biodiversity.

Together with journalist Kristina Michahelles, Jürgen recently concluded the publication of a biography of his wife titled: "Hanne, Johanna Döbereiner: a life dedicated to science" (Michahelles 2018).

In 2010 after 55 years of service, Dr. Jürgen retired at the age of 86. But he continued as unpaid general editor of the Pesq. Vet. Bras. from 1981 until the last day of his life.

In memory of his philosophy he left a document entitled: "Carta de Porangaba", where together with his collaborators he had developed a modern approach to assist and improve the pubic animal health service in Brazil, in particular the field of veterinary science through an Integrated Animal Health System (SISA).

Jürgen loved to talk about the adventures of his multiple field trips and there is plenty of cinematographic material available, which will be edited to produce a documentary titled: Stories on Animal Health Research in Brazil.

Dr. Jürgen Döbereiner passed away suddenly and peacefully on the 16th of October 2018 at the age of 94 in his house.

Acknowledgments.- We thank Prof. Jeann Leal de Araújo for the outstanding quality and artistic images.

\section{REFERENCES / REFERÊNCIAS}

Blobel H., Döbereiner J., Lima F.G.F. \& Rosa I.V. 1984. Bacterial isolations from Cara Inchada lesions of cattle. Pesq. Vet. Bras. 4(2):73-77.

Blobel H., Döbereiner J., Rosa I.V., Lima F.G.F. \& Dutra I.S. 1987. Bacterial investigations of a periodontal disease - Cara Inchada - of cattle in Brazil. Tierärztl. Umsch. 42:152-157.

Borsanelli A.C., Gaetti-Jardim Júnior E., Döbereiner J. \& Dutra I.S. 2015a. Treponema denticola in microflora of bovine periodontitis. Pesq. Vet. Bras. 35(3):237-240. <http://dx.doi.org/10.1590/S0100-736X2015000300005>

Borsanelli A.C., Gaetti-Jardim Júnior E., Schweitzer C.M., Döbereiner J. \& Dutra I.S. 2015b. Presence of Porphyromonas and Prevotella species in the oral microflora of cattle with periodontitis. Pesq. Vet. Bras. 35(10):829-834. <http://dx.doi.org/10.1590/S0100-736X2015001000002>

Botteon R.M., Dutra I.S., Döbereiner J. \& Blobel H. 1993. Caracterização de bactérias isoladas das lesões peridentárias da Cara Inchada dos bovinos. Pesq. Vet. Bras. 13(3/4):51-55.

Curci V.C.L.M., Dutra I.S., Döbereiner J. \& Lucas Junior J. 2007. Pré-compostagem de cadáveres de bovinos acometidos pelo botulismo. Pesq. Vet. Bras. 27(4):157-161. <http://dx.doi.org/10.1590/S0100-736X2007000400005>

Dämmrich K., Döbereiner J., Done S.H. \& Tokarnis C.H. 1975. Skeletal changes after Solanum malacoxylon poisoning in cattle. Zentralbl. Veterinärmed. 22(4):313-329. <PMid:806210>

Döbereiner J. 2005. Diários de viagem de Jürgen Döbereiner: 1969-2005. 13 Vol.

Döbereiner J. \& Dämmrich K. 1974. Skeletal lesions after poisoning of cattle by Solanum malacoxylon. Verh. Dtsch. Ges. Pathol. 58:323-326.<PMid:4460478> (sua esposa) e seus três filhos Maria Luisa, Cristian e Lorenz. Convém mencionar que Dr. Döbereiner estava concentrando suas energias nos finais de semana no seu "Sítio Porangaba" (Fig.4), umas das primeiras Reservas Particulares de Patrimônio Natural (RPPN) do Estado do Rio de Janeiro, situado na Mata Atlântica da Serra do Mar, em Itaguaí/RJ. Ele foi um dos fundadores e o presidente da Associação do Patrimônio Natural (APN) e demonstrava exemplo em contribuir na conservação da biodiversidade.

Recentemente Dr. Jürgen Döbereiner desenvolveu a publicação do livro "Hanne, Johanna Döbereiner: uma vida dedicada à ciência" sobre a vida de sua esposa, que foi escrito pela jornalista Kristina Michahelles (2018).

Após 55 anos de serviço, em 2010 Dr. Jürgen se aposentou com 86 anos de idade, mas continuou atuando, desde 1981 como editor geral da revista Pesq. Vet. Bras. até o último dia de sua vida. Ele deixou um documento intitulado "Carta de Porangaba", em homenagem ao seu sítio, onde desenvolveu junto com colaboradores um projeto para o aperfeiçoamento dos serviços veterinários no Brasil por meio de um Sistema Integrado de Saúde Animal (SISA).

Jürgen gostava de contar sobre suas aventuras durante viagens a campo, portanto realizaram-se filmagens de grande parte dessas histórias, as quais serão editadas para a preparação de um documentário intitulado por Jürgen como Histórias de Pesquisa em Saúde Animal no Brasil.

Dr. Jürgen Döbereiner com 94 anos, faleceu em casa no dia 16 de outubro de 2018.

Agradecimentos.- Agradecemos o Prof. Jeann Leal de Araújo pela excelente qualidade artística das imagens.

Döbereiner J. \& Dämmrich K. 1997. Are alveolar changes a determinant factor for cara inchada in cattle? Pesq. Vet. Bras. 17(2):45-48. <http:// dx.doi.org/10.1590/S0100-736X1997000200001>

Döbereiner J. \& Tokarnia C.H. 1959a. Ocorrência da coriza gangrenosa dos bovinos no município de Serra Negra do Norte Rio Grande do Norte. Arqs Inst. Biol. Anim. 2:65-82.

Döbereiner J. \& Tokarnia C.H. 1959b. Intoxicação de bovinos pela erva de rato (Palicourea marcgravii St.Hil.) no Vale do Itapicuru Maranhão. Arqs Inst. Biol. Anim. 2:83-91.

Döbereiner J., Done S.H. \& Beltran L.E. 1975a. Experimental Solanum malacoxylon poisoning in calves. Brit. Vet. J. 131(2):175-185. < http:// dx.doi.org/10.1016/S0007-1935(17)35338-1><PMid:1137803>

Döbereiner J., Chaves J.A., Rosa I.V. \& Houser R.H. 1975b. Efeito da transferência de bovinos com Cara Inchada (doença peridentária) para pastos de região indene. Pesq. Agropec. Bras. 10:99-103.

Döbereiner J., Inada T. \& Tokarnia C.H. 1974. Cara Inchada, doença peridentária em bovinos. Pesq. Agropec. Bras. 9:53-85.

Döbereiner J., Rosa I.V. \& Lazzari A.A. 1976. Cara Inchada (doença peridentária) em bezerros mantidos em pastos de Panicum maximum. Pesq. Agropec Bras. 11:43-47.

Döbereiner J., Rosa I.V. \& Lazzari A.A. 1987. Efeito do leite materno sobre as lesões peridentárias da Cara Inchada em bezerros. Pesq. Vet. Bras. 7(3):97-99.

Döbereiner J., Tokarnia C.H. \& Canella C.F.C. 1967. Ocorrência da hematúria enzoótica e de carcinomas epidermóides no trato digestivo superior em bovinos no Brasil. Pesq. Agropec. Bras. 2:489-504.

Döbereiner J., Collins Jr. W.T., Capen C.C. \& Tokarnia C.H. 1977. Ultrastructural evaluation of parathyroid glands and thyroid C cells of cattle fed Solanum malacoxylon. Am. J. Pathol. 87(3):603-614. <PMid:869016> 
Döbereiner J., Dutra I.S. \& Rosa I.V. 2004. A etiologia da "cara inchada", uma periodontite epizoótica dos bovinos. Pesq. Vet. Bras. 24(1):50-56

Döbereiner J., Tokarnia C.H., Langenegger J. \& Dutra I.S. 1992. Epizootic botulismo of cattle in Brazil. Deutsche Tierärztliche Wochenschrift 99(5):188-190. <PMid:1638962>

Döbereiner J., Olson C., Brown R.R., Price J.M. \& Yess N. 1966. Metabolites in urine of cattle with experimental bladder lesions and fed bracken fern. Pesq. Agropec. Bras. 1:189-199.

Döbereiner J., Rosa I.V., Dutra I.S., Pereira A.R. \& Blobel H. 1990. Efeito de espiramicina na profilaxia da Cara Inchada dos bovinos. Pesq. Vet. Bras. 10(1/2):27-29.

Döbereiner J., Tokarnia C.H., Costa J.B.D., Campos J.L.E. \& Dayrell M.S. 1971 Espichamento intoxicação de bovinos por Solanum malacoxylon no Pantanal de Mato Grosso. Pesq. Agropec. Bras. 6:91-117.

Done S.H., Döbereiner J. \& Tokarnia C.H. 1976a. Systemic connective tissue calcification in cattle poisoned by Solanum malacoxylon: a histological study. Brit. Vet. J. 132(1):28-38. <http://dx.doi.org/10.1016/S00071935(17)34785-1><PMid:1260412>

Done S.H., Tokarina C.H., Dämmrich K. \& Döbereiner J. 1976b. Solanum malacoxylon poisoning in pigs. Res. Vet. Sci. 20(2):217-219.<http://dx.doi. org/10.1016/S0034-5288(18)33461-1><PMid:1265362>

Dutra I.S., Botteon R.M. \& Döbereiner J. 2000. Modificações da microbiota associada às lesões peridentárias da cara inchada em bezerros transferidos para área indene. Pesq. Vet. Bras. 20(2):71-74. <http://dx.doi.org/10.1590/ S0100-736X2000000200003>

Dutra I.S., Matsumoto T. \& Döbereiner J. 1993a. Surtos de periodondite em bezerros (Cara Inchada) associados ao manejo do solo. Pesq. Vet. Bras. 13(1/2):1-4

Dutra I.S., Weiss H.E. \& Döbereiner J. 1993b. Diagnóstico do botulismo em bovinos no Brasil pela técnica de microfixação de complemento. Pesq. Vet. Bras. 13(3/4):83-86.

Dutra I.S., Rosa I.V. \& Blobel H. 2000. Cara inchada of cattle an infectious apparently soil antibiotics-dependant periodontitis in Brazil. Pesq. Vet. Bras. 20(2):47-64

Dutra I.S., Döbereiner J. \& Souza A.M. 2005. Botulismo em bovinos alimentados com cama de frango. Pesq. Vet. Bras. 25(2):115-119. <http://dx.doi. org/10.1590/S0100-736X2005000200009>

Dutra I.S., Döbereiner J., Rosa I.V., Souza L.A.A. \& Nonato M. 2001. Surtos de botulismo em bovinos no Brasil associados à ingestão de água contaminada. Pesq. Vet. Bras. 21(2):43-48. <http://dx.doi.org/10.1590/ S0100-736X2001000200002>

Grassmann B., Döbereiner J., Dutra I.S., Kopp P.A. \& Blobel H. 1997. Adherence and experimental infection of bacteria associated with periodontal infections of young cattle in Brazil (Cara inchada). Pesq. Vet. Bras. 17(3/4):123-125. <http://dx.doi.org/10.1590/S0100-736X1997000300006>

Kopp P.A., Dutra I.S., Döbereiner J., Schmitt M., Grassmann B. \& Blobel H. 1996. Estreptomicina aumenta a aderência em células epiteliais de Bacteroides melaninogenicus associado às lesões peridentárias. Pesq. Vet. Bras. 16(2/3):53-57.

Langenegger J. \& Döbereiner J. 1988. Botulismo enzoótico em búfalos no Maranhão. Pesq. Vet. Bras. 8(1/2):37-42

Langenegger J., Döbereiner J. \& Lima A.C. 1960. Foco de môrmo (Malleus) na região de Campos Estado do Rio de Janeiro. Arqs Inst. Biol. Anim. 3:91-108.

Malafaia P., Costa R.M., Brito M.F., Peixoto P.V., Barbosa J.D., Tokarnia C.H. \& Döbereiner J. 2014. Equívocos arraigados no meio pecuário sobre deficiência e suplementação mineral em bovinos no Brasil. Pesq. Vet. Bras. 34(3):244-249. <http://dx.doi.org/10.1590/S0100-736X2014000300008>
Menegucci E.A., Dutra I.S. \& Döbereiner J. 1998. Sensibilidade toxicológica e especificidade do teste de microfixação de complemento na detecção de toxinas C e D em meio de cultura e fígado de camundongos. Pesq. Vet. Bras. 18(2):47-52. <http://dx.doi.org/10.1590/S0100-736X1998000200001>

Michahelles K. 2018. Hanne, Johanna Döbereiner: uma vida dedicada à ciência. Trio Studio Editora e Gráfica Digital, Rio de Janeiro. 102p.

Moraes S.S., Tokarnia C.H. \& Döbereiner J. 1999. Deficiências de microelementos em bovinos e ovinos em algumas regiões do Brasil. Pesq. Vet. Bras. 19(1):1933. <http://dx.doi.org/10.1590/S0100-736X1999000100004>

Pessoa C.R.M., Medeiros R.M.T. \& Riet-Correa F. 2013. Importância econômica, epidemiologia e controle das intoxicações por plantas no Brasil. Pesq. Vet. Bras. 33(6):752-758. <http://dx.doi.org/10.1590/S0100-736X2013000600011>

Pilati C., Dutra I.S., Behrens K., Döbereiner J. \& Dämmrich K. 1996. Diagnóstico da deficiência de fósforo em bovinos pelos exames histológicos e microrradiográficos de costelas. Pesq. Vet. Bras. 16(1):27-33.

Rosa I.V., Döbereiner J. \& Blobel H.O. 1985. Efeito de tratamento com antibióticos sobre as lesões peridentárias da Cara Inchada dos bovinos. Pesq. Vet. Bras. 5(1):5-9.

Sansom B.F., Vagg M.J. \& Döbereiner J. 1971. The effects of Solanum malacoxylon on calcium metabolism in cattle. Res. Vet. Scie. 12(6):604-605. <http:// dx.doi.org/10.1016/S0034-5288(18)34126-2><PMid:5145360>

Schmitt M., Dutra I.S., Döbereiner J., Kopp P.A. \& Blobel H. 1996. Cara Inchada and cellular immunity in cattle. Pesq. Vet. Bras. 16(1):1-3.

Silva T.M.D., Dutra I.S., Castro R.N. \& Döbereiner J. 1998. Ocorrência e distribuição de esporos de Clostridium botulinum tipos C e D em áreas de criação de búfalos na Baixada Maranhense. Pesq. Vet. Bras. 18(3/4):127131. <http://dx.doi.org/10.1590/S0100-736X1998000300007>

Souza A.M., Marques D.F., Döbereiner J. \& Dutra I.S. 2006. Esporos e toxinas de Clostridium botulinum dos tipos C e D em cacimbas no Vale do Araguaia Goiás. Pesq. Vet. Bras. 26(3):133-138. <http://dx.doi.org/10.1590/S0100736X2006000300001>

Tims F.M., Dutra I.S., Matsumoto T. \& Döbereiner J. 1992. Eficiência de Virginiamicina na Cara Inchada dos bovinos. Pesq. Vet. Bras. 12(3):77-80.

Tokarnia C.H. \& Döbereiner J. 1974. Espichamento intoxicação de bovinos por Solanum malacoxylon no Pantanal de Mato Grosso. II. Estudos complementares. Pesq. Agropec. Bras. 9:53-62.

Tokarnia C.H., Döbereiner J. \& Canella C.F.C. 1959. Estudo sobre o mal dos chifres em gado do Nordeste e Norte do Brasil. Arqs Inst. Biol. Anim. 2:83-91.

Tokarnia C.H., Döbereiner J. \& Canella C.F.C. 1969. Ocorrência da hematúria enzoótica e de carcinomas epidermóides no trato digestivo superior em bovinos no Brasil. II. Estudos complementares. Pesq. Agropec. Bras. $4: 209-224$

Tokarnia C.H., Döbereiner J. \& Moraes S.S. 1988. Situação atual e perspectivas da investigação sobre nutrição mineral em bovinos no Brasil. Pesq. Vet. Bras. 8(1/2):1-16

Tokarnia C.H., Döbereiner J. \& Peixoto P.V. 1994. Aspectos clinico-patológicos complementares da intoxicação por algumas plantas tóxicas brasileiras. Pesq. Vet. Bras. 14(4):111-122.

Tokarnia C.H., Döbereiner J. \& Peixoto P.V. 2000a. Plantas Tóxicas do Brasil Para Animais de Produção. Editora Helianthus. 310p.

Tokarnia C.H., Döbereiner J. \& Peixoto P.V. 2000b. Deficiências minerais em animais de fazenda principalmente bovinos em regime de campo. Pesq. Vet. Bras. 20(3):127-138. <http://dx.doi.org/10.1590/S0100736X2000000300007>

Tokarnia C.H., Döbereiner J. \& Peixoto P.V. 2002. Poisonous plants affecting livestock in Brazil. Toxicon 40(12):1635-1660. <http://dx.doi.org/10.1016/ S0041-0101(02)00239-8><PMid:12457875> 
Tokarnia C.H., Döbereiner J. \& Silva M.F. 1979. Plantas Tóxicas da Amazônia a Bovinos e Outros Herbívoros. Instituto Nacional de Pesquisas da Amazônia, Manaus, AM. 95p.

Tokarnia C.H., Döbereiner J., Moraes S.S. \& Peixoto P.V. 1999. Deficiências e desequilíbrios minerais em bovinos e ovinos - revisão dos estudos realizados no Brasil de 1987 a 1998. Pesq. Vet. Bras. 19(2):47-62. <http:// dx.doi.org/10.1590/S0100-736X1999000200001>

Tokarnia C.H., Brito M.F., Barbosa J.D., Peixoto P.V. \& Döbereiner J. 2012. Plantas Tóxicas do Brasil. $2^{\text {a }}$ ed. Editora Helianthus, Rio de Janeiro, RJ. 566p.

Tokarnia C.H., Langenegger J., Langenegger C.H. \& Carvalho E.V. 1970. Botulismo em bovinos no Piauí, Brasil. Pesq. Agropec. Bras. 5:465-472.

Tokarnia C.H., Peixoto P.V., Barbosa J.D., Brito M.F. \& Döbereiner J. 2010. Deficiências Minerais em Animais de Produção. Helianthus, Rio de Janeiro. 191p.
Tokarnia C.H., Peixoto P.V., Döbereiner J., Barros S.S. \& Riet-Correa F. 2004. O surto de peste suína africana ocorrrido em 1978 no município de Paracambi, Rio de Janeiro. Pesq. Vet. Bras. 24(4):223-238. <http://dx.doi. org/10.1590/S0100-736X2004000400010>

Tokarnia C.H., Döbereiner J., Peixoto P.V., Barbosa J.D., Brito M.F. \& Silva M.F. 2007. Plantas Tóxicas da Amazônia a Bovinos e Outros Herbívoros. $2^{\underline{a}}$ ed. Instituto Nacional de Pesquisas da Amazônia, Manaus, AM. 97p.

Tokarnia C.H., Döbereiner J., Canella C.F.C., Couceiro J.E.M., Silva A.C.C. \& Araújo F.V. 1981. Intoxicação de bovinos por Thiloa glaucocarpa (Combretaceae), no Nordeste do Brasil. Pesq. Vet. Bras. 1(4):111-132.

Viana F.C. 2008. História e Memória da Peste Suína Africana no Brasil: passos e descompassos. FEPMVZ Editora, Belo Horizonte, MG. 266p. 